\title{
Imaging diagnostics for primary hyperparathyroidism
}

\author{
Diagnostyka obrazowa pierwotnej nadczynności przytarczyc \\ Jacek Gawrychowski, Grzegorz Buła \\ Department of General Surgery, Silesian Medical University, Katowice, Poland \\ Department of General Surgery and Endocrinological Surgery, Hospital Nr 2, Bytom, Poland
}

\begin{abstract}
Primary hyperparathyroidism (PHP) is a benign condition characterised by malignant potential. Even in specialist wards, 5-10\% of operations for PHP are unsuccessful. The main reasons seem to be ectopy of the parathyroid gland, numerous adenomas, multiglandular parathyroid hyperplasia, and intrathyroid location of the parathyroid. The last three decades have witnessed a rapid progression in imaging diagnostics. (Endokrynol Pol 2013; 64 (5): 404-408)
\end{abstract}

Key words: primary hyperparathyroidism, ultrasonography, scintigraphy MIBI

\section{Streszczenie}

Pierwotna nadczynność przytarczyc (PNP) jest chorobą łagodną o złośliwym potencjale. Nawet w ośrodkach specjalistycznych 5-10\% operacji z powodu pierwotnej nadczynności przytarczyc (PNP) kończy się niepowodzeniem. Główną tego przyczyną wydają się być ektopia przytarczyc, obecność mnogich gruczolaków, przerost guzkowy przytarczyc oraz wewnątrztarczycowa lokalizacja przytarczyc. Ostatnie trzy dekady przyniosły gwałtowny postęp diagnostyki obrazowej. (Endokrynol Pol 2013; 64 (5): 404-408)

Słowa kluczowe: pierwotna nadczynność przytarczyc, ultrasonografia, scyntygrafia MIBI

Primary hyperparathyroidism (PHP) is a benign condition characterised by malignant potential. If left untreated, it will double the risk of developing a cancer of the breast, prostate or large intestine. It will also cause an increase in heart diseases, hypertensive diseases and osteoporosis. Roughly one third of patients with primary hyperparathyroidism suffer from nephrolithiasis, and most of them complain of a reduction in their quality of life. It is important to note that patients with a 15 year-long history are seen very rarely, and over that time practically never [1].

Why then do surgeons try to avoid operations on patients with the disease diagnosed biochemically but showing a negative result of imaging examinations? Based on experience, lack of disease imaging is not a contraindication to operative treatment. On the other hand, such patients are often a very grateful subject of said management [2]. However, it is widely known that the picture of parathyroid glands correlates well with the clinical severity of the disease [3].

Even in specialist wards, $5-10 \%$ of operations for PHP are unsuccessful [4]. The main reasons seem to be ectopy of the parathyroid gland, numerous adenomas, multiglandular parathyroid hyperplasia, and intrathyroid location of the parathyroid [5-8].
The statement of the radiologist J.Doppman in 1968 that "the only localisation study needed by a patient undergoing initial parathyroid surgery is to locate an experienced parathyroid surgeon" [9] was still valid in 1986 during the conference held by the National Institutes of Health on the diagnostics of parathyroid glands.

Since that time, a rapid progression of imaging diagnostics has taken place. Now it is quite easy to define a highly accurate location of disease-transformed parathyroid glands. The advantages of such accurate localisation are obvious.

First of all it is very important to shorten the length of the operation and to reduce the number of unsuccessful operations. Also, a limited preparation area allows a reduced risk of complications, which shortens the time of postoperative care and helps to lower the costs of treatment [10-12].

In light of the above, imaging examinations of parathyroid glands should be:

- highly sensitive

- highly specific

- as minimally invasive as possible

- cost-effective

- available [13].

Prof. Jacek Gawrychowski M.D., Hospital of General Surgery and Endocrinological Surgery, Batorego St.15, 41-902 Bytom, Katowice, Poland, tel. +483278615 18, e-mail: jacekgaw@o2.pl 
Table I. Examinations enabling identification of disease-transformed parathyroid glands Tabela I. Badania pozwalające na identyfikację chorobowo zmienionych przytarczyc

\begin{tabular}{|c|c|c|}
\hline \multicolumn{3}{|c|}{ Examinations } \\
\hline \multicolumn{2}{|r|}{ Preoperative } & \multirow[t]{2}{*}{ Intraoperative } \\
\hline Non-invasive & Invasive & \\
\hline 1. USG & 1. BAC & 1. USG \\
\hline 2. CT & 2. Selective arteriography/thyrocervicaltrunk, internal thoracic artery, & 2. Scintillating probe \\
\hline 3. MR & cervical arteries, superior thyroid arteries & 3. ОРТH \\
\hline 4. Scintigraphy & 3. SVS selective venous blood sampling for PTH determination & 4. Methylene blue \\
\hline — subtraction (thallium technetium) & & 5. Histopathological \\
\hline — 'washout' (SPECT)/Tc99m sestamibi & & examination \\
\hline 5. PET & & \\
\hline
\end{tabular}

High sensitivity and specificity of the examination are closely related to the experience of the examiner. It is also important that the requisition form has been properly completed, giving full information not only on the history but also on laboratory findings. The quality of the picture is important too [13-16].

It is definitely true that imaging diagnostics can enable the surgeon to perform a minimally invasive parathyroidectomy (MIP) in a safe way $[1,17]$.

An analysis of data from 15 American hospital centres revealed that the costs of an operation for PHP with bilateral neck exploration were \$1,773 USD and with unilateral neck exploration $\$ 1,123$ USD including the costs of scintigraphy (sestamibi). Total costs including the description were \$429 USD (examination - \$305 USD, description - \$124 USD). Reducing the costs is undoubtedly connected to the length of the operation. A bilateral exploration takes usually $109.3 \pm 29 \mathrm{~min}$., and a unilateral $49.29 \mathrm{~min}$. [17-20].

Examinations performed to enable identification of disease-transformed parathyroid glands are shown in Table I.

One of the most generally available and relatively cheap examinations is ultrasonography (USG) [21-23]. Unfortunately, the sensitivity of this examination, usually $71-80 \%$, is to a great degree dependent on the experience of the examiner [24,25]. So USG can be more or less sensitive (30-90\%) depending on the experience and skill of the examiner [6, 23, 26, 27] (Table II). USG does not enable localisation of parathyroid glands placed in the mediastinum or in retrotracheal or retrooesophageal regions due to acoustic shadows from bones or air spaces. On the other hand, the latter region can be excellently shown by transoesophageal USG [21, $26,28,29$ ]. Moreover, USG enables better imaging of an adenoma located within the thyroid gland [30], in spite of the ease with which a thyroid tuberculum can be confused with an adenoma.
It is well known that a nodular goitre is detected in $6-15 \%$ of PHP patients. Generally, PHP is estimated to coexist with other thyroid diseases in $18-84 \%$ of patients $[1,31,32]$.

Massive nodular goitres restrict the visualisation of structures located backwards of the thyroid gland through:

reducing the sound wave,

displacing adjacent structures by mass effect,

overlapping acoustic shadows [33, 34].

If USG is performed by a surgeon (adequately experienced of course), sensitivity and accuracy of such examination are $87 \%$ and $88 \%$ respectively [10]. If the result has been assessed as 'atypical' or negative, PTH level in jugular vein blood is measured.

The term 'atypical' refers to the picture in which the examiner:

- is not able to differentiate an ectopic parathyroid gland from a transformed lymph node in jugular region;

- suspects a parathyroid gland as the lesion is only partially visualized;

- is not able to differentiate a hypoechogenic lesion from a thyroid tuberculum or a cyst located in posterior part of the neck;

- has found a bilateral suspicious lesion, 'atypical' with reference to a parathyroid gland [10].

Therefore, an 'atypical' result of a USG examination does not mean a negative result.

USG does not seem very useful for the evaluation of hyperplastic parathyroid glands [25]. In secondary parathyroidism, sensitivity of the examination is $60 \%$ and specificity $64 \%$. If the lesions are connected with more than one parathyroid gland, false diagnoses cover nearly $30 \%$ of patients [34].

If a parathyroid gland is ectopically located in the anterior mediastinum or retro-oesophageal region, computed tomography is a great help [35]. Sensitivity 
Table II. Characteristics of non-invasive methods to localise disease-transformed parathyroid glands Tabela II. Charakterystyka nieinwazyjnych metod obrazowych w diagnostyce chorobowo zmienionych przytarczyc

\begin{tabular}{|c|c|c|c|c|c|}
\hline \multirow[t]{3}{*}{ Factor } & \multicolumn{5}{|c|}{ Localization method } \\
\hline & \multirow[t]{2}{*}{ USG } & \multirow[t]{2}{*}{ CT with contrast } & \multirow[t]{2}{*}{ MR } & \multicolumn{2}{|c|}{ Scintigraphy } \\
\hline & & & & $\mathrm{TI} / \mathrm{Tc}$ & Tc99m sestamibi \\
\hline & $71-80$ & $46-80$ & $64-88$ & 75 & 90.7 \\
\hline Sensitivity (\%) & /range 30-90/ & & & & \\
\hline Specificity (\%) & $80-89$ & 80 & $88-95$ & $73-82$ & 98.8 \\
\hline Reoperation Sensitivity (\%) & 40 & & $50-88$ & 50 & \\
\hline Falsely positive (\%) & $15-20$ & 50 & 18 & 25 & Low \\
\hline Dependent on examiner's skill & +++ & + & ++ & No & No \\
\hline Exposure to radiation & No & ++ & No & + & + \\
\hline Costs & + & +++ & ++++ & ++ & ++ \\
\hline
\end{tabular}

of this examination can be as high as $92 \%$ [36, 37]. However, it is less sensitive than magnetic resonance (MR), and a high percentage of false positive results (up to $50 \%$ ) is also involved. For this reason, and also due to the necessary contrast, a far better method to examine ectopic parathyroid glands seems to be MR, in spite of the higher costs [30].

In a CT picture, a parathyroid adenoma can be difficult to differentiate from lymph nodes, normal vessel structures or an exophytic thyroid tuberculum, particularly in patients who have previously undergone an operation within the neck [38,39].

The characteristics of non-invasive methods for localising transformed parathyroid glands indicate that the best of them is isotopic radiodiagnostics, particularly technet scintigraphy Tc99m sestamibi $[15,17$, 40]. This radiotracer is easily assimilated both by the thyroid gland and by the parathyroid. However, it is soon washed out from the thyroid, whereas parathyroid glands have the ability to store it [41]. Compared to scintigraphy based on isotope Thal201, Technet99m sestamibi is safer when administered in higher doses and has closer affinity with parathyroid tissues. Sensitivity of this examination ranges from $85 \%$ to $100 \%$, the latter in the case of parathyroid adenoma [42, 43]. But Technet99m sestamibi is less useful for diagnosing parathyroid hyperplasia as only one gland is identified. Advantages and disadvantages of non-invasive methods used to localise disease-transformed parathyroid glands are shown in Table III.

It should be stressed here that MIBI is a function test and not an anatomical examination. Therefore a smaller gland may reduce its sensitivity [28, 44, 45].

There are three types of technet scintigraphy:

- monoisotopic and two-stage type - scintigraphic pictures are interpreted after 15 minutes and with an interval of 2-3 hours; quicker elimination of the tracer from the thyroid than from the parathyroid plays a role;

- subtraction bi-isotopic type - the thyroid is first examined using e.g. iodine J123 or Tc $99 \mathrm{~m}$ pertechnet, and the picture is 'subtracted' from the one obtained upon administration of Technet $99 \mathrm{~m}$ sestamibi $[46,47]$;

- three-dimensional examinations SPECT (Single Photon Emission Computed Tomography) [5, 38, 48].

Using USG together with Tc99sestamibi enables the examiner to obtain higher sensitivity of the picture from $10 \%$ to even $30 \%$ [13]. Statistical analyses have revealed that further independent factors affecting the accuracy of the two diagnostic tests are body mass index (BMI) and the size of the thyroid gland [8]. If MIBI and USG give a negative result, it is recommended to perform MRI or stereoscopic computed tomography (4D-CT) [36].

It must be stressed that if a reoperation is necessary in patients with persistent primary hyperparathyroidism, the most sensitive examination (50-88\%) among non-invasive types will be magnetic resonance (MR) $[49,50]$.

Invasive methods used for diagnosing primary hyperparathyroidism are much more sensitive. Selective angiography shows $60 \%$ sensitivity, and intra-operative determination of parathormone in venous blood $80 \%$. If both examinations are used, the sensitivity will increase to as much as 91-95\% [50-52]. These examinations help to accurately localise an adenoma (angiography) and to identify further adenomas or hyperplasia (PTH in venous blood) [51]. Unfortunately, the methods may involve dangerous complications, including neurological disorders, embolism or renal failure. 
Table III. Advantages and disadvantages of non-invasive methods to localise disease-transformed parathyroid glands Tabela III. Zalety $i$ niedogodności metod obrazowych w diagnostyce chorobowo zmienionych przytarczyc

\begin{tabular}{|c|c|c|c|c|c|}
\hline \multirow[t]{3}{*}{ Factor } & \multicolumn{5}{|c|}{ Localisation method } \\
\hline & \multirow[t]{2}{*}{ USG } & \multirow[t]{2}{*}{ CT with contrast } & \multirow[t]{2}{*}{ MR } & \multicolumn{2}{|c|}{ Scintigraphy } \\
\hline & & & & $\mathrm{Tl} / \mathrm{Tc}$ & Tc99m sestamibi \\
\hline Advantages & $\begin{array}{l}\text { Cheap } \\
\text { Quick } \\
\text { Avoids radiation and } \\
\text { contrast i.v. } \\
\text { Easy to use together } \\
\text { with BAC } \\
\text { Transoesophageal } \\
\text { USG: good evaluation } \\
\text { of posteriori neck and } \\
\text { perioesophageal }\end{array}$ & $\begin{array}{l}\text { Good evaluation of } \\
\text { mediastinum, retro- } \\
\text { oesophageal and } \\
\text { retrotracheal spaces } \\
\text { Easy to use together } \\
\text { with BAC }\end{array}$ & $\begin{array}{l}\text { Enables localisation of } \\
\text { ectopic dose glands } \\
\text { Useful if scintigraphy } \\
\text { unsuccessful } \\
\text { No need to use ionic } \\
\text { contrast }\end{array}$ & $\begin{array}{l}\text { Readily available } \\
\text { Minimal dose of } \\
\text { radiation }\end{array}$ & $\begin{array}{c}\text { Best available to localise } \\
\text { Minimal dose of } \\
\text { radiation } \\
\text { Readily available } \\
\text { Excellent anatomical } \\
\text { localisation with SPECT }\end{array}$ \\
\hline Disadvantages & $\begin{array}{c}\text { Difficult to evaluate } \\
\text { to posteriori neck and } \\
\text { mediastinum } \\
\text { Not possible to } \\
\text { recognise lesions nodes } \\
<5 \mathrm{~mm} \\
\text { Dependent on } \\
\text { examiner's skill } \\
\text { Transoesophageal USG } \\
\text { difficult to evaluate } \\
\text { lateral and/or anterior } \\
\text { spaces }\end{array}$ & $\begin{array}{l}\text { Difficult to differentiate } \\
\text { small lesions (lymph, } \\
\text { parathyroid adenoma) } \\
\text { in lower neck and } \\
\text { periscapular spaces and } \\
\text { thyroid }\end{array}$ & $\begin{array}{l}\text { expensive } \\
\text { Not to be used together } \\
\text { with BAC } \\
\text { Limited use because of } \\
\text { claustrophobia } \\
\text { Not possible to evaluate } \\
\text { lesions }<5 \mathrm{~mm}\end{array}$ & $\begin{array}{l}\text { Poor topographic } \\
\text { evaluation } \\
\text { Limited sensitivity }\end{array}$ & $\begin{array}{c}\text { May } 4 \text { hyperplastics } \\
\text { glands or a few } \\
\text { adenomas unidentified }\end{array}$ \\
\hline
\end{tabular}

Intra-operative determination of parathormone (IOPTH) helps the examiner to decide whether it is better to extend the operation, or instead to end it, if: - a suspicious hyperplastic gland has been removed but the hormone level does not go down;

- an abnormal parathyroid gland has been found although not confirmed by imaging examinations (in such a case, bilateral exploration of the neck is avoided to decrease the risk of complications);

- the diseased gland is not clearly recognisable (an answer is given as to which part of the neck should be explored; even a 5\% difference can play a decisive role);

- thin-needle biopsy has been performed to examine the tissue in question (bioptate is placed in $1 \mathrm{~mL}$ of physiological saline; the presence of the parathyroid tissue is confirmed if PTH level is higher than 1,500 $\mathrm{pg} / \mathrm{mL})[52,53]$.

- In light of the available data, it seems that patients with primary hyperparathyroidism should receive USG of the neck and scintigraphy MIBI in the first place to identify the lesions [54-58]. If any discrepancies occur in the results, MR is recommended. Operation should be decided afterwards. Levels of parathormone should be monitored throughout the operation [59-63].

\section{Reference}

1. Norman J. Controversies in parathyroid surgery: The quest for a "mini" unilateral parathyroid operation seems to have gone too far. J Surg Oncol 2012; 105: 1-3.

2. Arici C, Cheah WK, Ituarte PH et al. Can localization studies be used to direct focused parathyroid operations? Surgery 2001; 129: 720-729.

3. Carneiro-Pla DM, Solorzano CC, Irvin GL. Consequences of targeted parathyroidectomy guided by localization studies without intraoperative parathyroid hormone monitoring. J Am Coll Surg 2006; 202: 715-722.

4. Howe JR. Minimally invasive parathyroid surgery. Surg Clin North Am 2000; 80: 1399-1426.

5. Solorzano CC, Lee TM, Ramirez MC et al. Surgeon - performed ultrasound improves localization of abnormal parathyroid glands. Am Surg 2005; 71: 557-563.

6. Uludag M, Isgor A, Yetkin G et al Supernumetary ectopic parathyroid glands. Persistent hyperparathyroidism due to mediastinal parathyroid adenoma localized by preoperative single photon emission computed tomography and intraoperative gamma probe application. Hormones 2009; 8: 144-149.

7. O'Doherty MJ, Kettle AG. Parathyroid imaging: preoperative localization. Nucl Med Com 2003; 24: 125-131.

8. Berber E, Parikh RT, Ballem N et al. Factors contributing to negative parathyroid localization: an analysis of 1000 patients. Surg 2008; 144: 74-79.

9. Doppman JL. Reoperative parathyroid surgery: localization procedures, parathyroid surgery. Prog Surg 1968; 18: 1171-1175.

10. Deutmeyer C, Weingarten M, Doyle $M$ et al. Case series of targeted parathyroidectomy with surgeon - performed ultrasonography as the only preoperative imaging study. Surgery 2011; 150: 1153-1160.

11. Zheng Y, Xu S, Wang P et al. Preoperative localization and minimally invasive management of primary hyperparathyroidism concomitant with thyroid disease. J Zhejiang Univ Sci B 2007; 8: 626-631.

12. Harari A, Allendorf J, Shifrin A et al. Negative preoperative localization leads to greater resource use in the era of minimally invasive parathyroidectomy. Am J Surg 2009; 197: 769-773.

13. Aleksandrides TK, Kouloubi K, Vagenakis AG et al. The value of scintigraphy and ultrasonography in the preoperative localization of parathyroid glands in patients with primary hyperparathyroidism and concomitant thyroid disease. Hormones 2006; 5: 42-51. 
14. Arveschoug AK, Bertelsen H, Vammen B. Presurgical localization of abnormal parathyroid glands usig a single injection of Tc-99m sestamibi comparison of high-resolution parallel-hole and pinhole collimators, and interobserver and intraobserver variation. Clin Nucl Med 2002; 27: 249-254.

15. Civelek AC, Ozalp E, Donovan P et al. Prospective evaluation of delayed technetium-99m sestamibi SPECT scintigraphy for preoperative localization of primary hyperparathyroidism. Surg 2002; 131: 149-157.

16. Elaraj DM, Sippel RS, Lindsay S et al. Are additional localization studies and referral indicated for patients with primary hyperparathyroidism who have negative sestamibi scan results? Arch Surg 2010; 145: 578-581.

17. Gurrado A, Piccinni G, Lissidini G et al. Hypercalcaemic crisis due to primary hyperparathyroidism - a systematic literature review and case report. Endokrynol Pol 2012; 63: 494-502.

18. Denham DW, Norman J. Cost-effectiveness of preoperative sestamibi scan for primary hyperparathyroidism is dependent solely upon the surgeon's choice of operative priocedure. J Am Coll Surg 1998; 186: 293-304.

19. Fahy BN, Bold RJ, Beckett L et al. A cost-benefit analysis of localizing strategies. Arch Surg 2002; 137: 917-923.

20. Morris LF, Zanocco K, Ituarte PHG et al. The value of intraoperative parathyroid hormone monitoring in localized primary hyperparathyroidism: a cost analysis. Ann Surg Oncol 2010; 17: 679-685.

21. Grosso I, Sargiotto A, D'Amelio P et al. Preoperative localization of parathyroid adenoma with sonography and $99 \mathrm{mTc}$-sestamibi scintigraphy in primary hyperparathyroidism. J Clin Ultrasound 2007; 35: 186-190.

22. Gurney TA, Orloff LA. Otolaryngologist-head and neck surgeonperformed ultrasonography for parathyroid adenoma localization. Laryngoscope 2008; 118: 243-246.

23. Haber RS, Kim CK, Inabnet WB. Ultrasonography for preoperative localization of enlarged parathyroid glands in primary hyperparathyroidism: comparison with ${ }^{99 \mathrm{~m}}$ technetium sestamibi scintigraphy. Clin Endocrin 2002; 57: 241-249.

24. Jabiev AA, Lew JI, Solorzano CC. Surgeon-performed ultrasound: a single institution experience in parathyroid localization. Surgery 2009; 146: 569-577.

25. Solorzano CC, Carneiro-Pla DM, Irvin GL. Surgeon performed ultrasonography as the initial and only localizing study in sporadic primary hyperparathyroidism. J Am Coll Surg 2006; 202: 18-24.

26. Huppert BJ, Reading CC. Parathyroid sonography: imaging and intervention. J Clin Ultrasound 2007; 35: 144-154.

27. Lee L, Steward DL. Techniques for parathyroid localization with ultrasound. Otolaryngol Clin N Am 2010; 43: 1229-1239.

28. Gough I. Reoperative parathyroid surgery: the importance of ectopic location and multigland disease. ANZ J Surg 2006; 76: 1048-1050.

29. Davis ML, Quayle FJ, Middleton WD et al. Ultrasound facilitates minimally invasive parathyroidectomy in patients lacking definitive localization from preoperative sestamibi scan. Am J surg 2007; 194: 785-791.

30. Amin AL, Wang TS, Wade TJ et al. Nonlocalizing imaging studies for hyperparathyroidism: where to explore first? J Am Coll Surg 2011; 213: 793-799.

31. Lorberboym M, Ezri T, Schachter PP. Preoperative technetium Tc $99 \mathrm{~m}$ sestamibi SPECT imaging in the management of primary hyperparathyroidism in Patients with concomitant multinodular goiter. Arch Surg 205; 140: 656-660.

32. Zald PB, Hamilton BE, Larsen ML et al. The role of computed tomography for localizationof parathyroid adenomas. Laryngoscope 2008; 118: 1405-1410.

33. Prager G, Czerny C, Kurtaran A et al. Minimally invasive open parathyroidectomy in an endemic goiter area. Arch Surg 2001; 136: 810-816.

34. Prager G, Czerny C, Ofluoglu S et al. Impact of localization studies on feasibility of minimally invasive parathyroidectomy in an endemic goiter region. J Am Coll Surg 2003; 196: 541-548.

35. Kawata R, Kotetsu L, Takamaki et al. Ultrasonography for preoperative localization of enlarged parathyroid glands in secondary hyperparathyroidism. Auris Nasus Larynx 2009; 36: 461-465.

36. Gawrychowski J, Gabriel A, Kluczewska E et al. Mediastinal parathyroid carcinoma: a case report. Endokrynol Pol 2012; 63: 143-146.

37. Mortenson MM, Evans DB, Lee JE et al. Parathyroid exploration in the reoperative neck: improved preoperative localization with $4 \mathrm{D}$-computed tomography. J Am Coll Surg 2008; 206: 888-896.

38. Profanter C, Prommegger R, Gabriel $\mathrm{M}$ et al. Computed axial tomography-MIBI image fusion for preoperative localization in primary hyperparathyroidism. Am J Surg 2004; 187: 383-387.

39. Rubello D, Casara D, Pagetta C et al. Determinant role of Tc-99m MIBI SPECT in the localization of a retrotracheal parathyroid adenoma successfully. Clin Nucl Med 2002; 27: 711-715.
40. Walczyk A, Szalecki M, Kowalska A. Primary hyperparathyroidism: a rare endocrinopathy in children. Two case reports. Endokrynol Pol 2011; 62: 346-350.

41. Rubello D, Pagetta C, Piotto A et al. Efficacy of sequential double tracer subtraction and SPECT parathyroid imaging in the precise localization of a low mediastinal parathyroid adenoma successfully removed surgically. Clin Nucl Med 2004; 29: 662-663.

42. Royal RE, Delpassand ES, Shapiro SE et al. Improving the yield of preoperative parathyroid localization: technetium Tc $99 \mathrm{~m}$-sestamibi imaging after thyroid suppression. Surgery 2002; 132: 968-975.

43. Ogawa T, Tsuji E, Kanauchi H et al. Excision of postesophageal parathyroid adenoma in posterior mediastinum with intraoperative $99 \mathrm{mTechne}$ tium sestamibi scanning. Ann Thorac Surg 2007; 84: 1754-1756.

44. Phitayakorn R, McHenry CR. Incidence and location of ectopic abnormal parathyroid glands. Am J Surg 2006; 191: 418-423.

45. Banzo I, Pena FJ, Allende RH et al. MIBI SPECT and surgery in the accurate location of a posterior mediastinal parathyroid adenoma. Clin Nucl Med 2003; 28: 584-586.

46. Barczyński M, Golkowski F, Konturek A et al. Technetium-99m-sestamibi subtraction scintigraphy vs. ultrasonography combined with a rapid parathyroid hormone assay in parathyroid aspirates in preoperative localization of parathyroid adenomas and in directing surgical approach. Clin Endocrin 2006; 65: 106-113.

47. Ho Shon IA, Roach PJ, Bernard EJ et al. Optimal pinhole techniques for preoperative localization with Tc-99m MIBI for primary hyperparathyroidism. Clin Nucl Med 2001; 26: 1002-1009.

48. Lindqvist $\mathrm{V}$, Jacobsson $\mathrm{H}, \mathrm{Chndanos} \mathrm{E}$ et al. preoperative ${ }^{99} \mathrm{Tc}^{\mathrm{m}}$-sestamibi scintigraphy with SPECT localizes most pathologic parathyroid glands. Langenbeck Arch Surg 2009; 394: 811-815.

49. Hessman O, Stalberg P, Sundin A et al. High success rate of parathyroid reoperation may be acheved with improved localization diagnosis. World J Surg 2008; 32: 774-781.

50. Nichols KJ, Tomas MB, Tronco GG et al. Preoperative parathyroid scintigraphic lesion localization: Accuracy of various types of readings. Radiology 2008; 248: 221-232

51. Haciyanli M, Lal G, Morita E et al. Accuracy of preoperative localization studies and intraoperative parathyroid hormone assay in patients with primary hyperparathyroidism and double adenoma. J Am Coll Surg 2003; 197: 739-746.

52. Munk RS, Payne RJ, Luria BJ et al. Preoperative localization in primary hyperparathyroidism. J Otolaryngology-Head \& Neck Surgery 2008; 37: 347-354.

53. Terzioglu T, Senyurek YG, Tunca F et al. Excision efficiency of radioguided occult lesion localization in reoperative thyroid and parathyroid surgery. Thyroid 2010; 20: 1271-1278.

54. Wild JL, Weigel T, Chen H. The need for intraoperative parathyroid hormone monitoring during radioguided parathyroidectomy by videoassisted thoracoscopy (VATS). Clin Nucl Med 2006; 31: 9-12.

55. Seehofer D, Steinmuller T, Rayes $\mathrm{N}$ et al. Parathyroid hormone venous sampling before reoperative surgery in renal hyperparathyroidism. Arch Surg 2004; 139: 1331-1338.

56. Schachter PP, Issa N, Shimonov Met al. Early, postinjection MIBI-SPECT as the only preoperative localizing study for minimally invasive parathyroidectomy. Arch Surg 2004; 139: 433-437.

57. Udelsman R, Aruny JE, Donovan PI et al. Rapid parathyroid hormone analysis during venous localization. Ann Surg 2003; 237: 714-721.

58. Anaforoglu I, Ersoy K, Algun E. Parathyroid adenoma with coeliac disease: primary or quaternary hyperparathyroidism? Endokrynol Pol 2012; 63: 56-58.

59. Scheiner JD, Dupuy DE, Monchik JM et al. Pre-operative localization of parathyroid adenomas: a comparison of power and colour doppler ultrasonography with nuclear medicine scintigraphy. Clin Radiol 2001; 56: 984-988.

60. Fraker DL, Harsono H, Lewis R. Minimally invasive parathyroidectomy: benefits and requirements of localization, diagnosis, and intraoperative PTH monitoring. Long-term results. World J Surg 2009; 33: 2256-2265.

61. Alesina PF, Singaporewalla RM, Walz MK. Video-assisted bilateral neck exploration in patients with primary hyperparathyroidism and failed localization. Studies. World J Surg 2010; 34: 2344-2349.

62. Lew JI, Solorzano CC, Montano RE et al. Role of intraoperative parathormone monitoring during parathyroidectomy in patients with discordant localization studies. Surgery 2008; 144: 299-306.

63. Buła G, Niemiec A, Truchanowski W et al. Śródoperacyjna ocena skuteczności leczenia chirurgicznego pierwotnej nadczynności przytarczyc. Pol Przeg Chir 2008; 80: 860-866. 